\title{
Femoral fractures in the elderly in Brasil - incidence, lethality, and costs (2008-2018)
}

\author{
Paula Antas Barbosa de Vasconcelos ${ }^{1}$ \\ (iD) Anderson de Jesus Rocha ${ }^{1}$ \\ (iD) Rodrigo Jorge de Souza Fonseca ${ }^{1}$ \\ (D) Thiago Rhangel Gomes Teixeira ${ }^{2}$ \\ (DiDilton de Santana Ribeiro Mattos ${ }^{3}$ \\ (iD) Alex Guedes ${ }^{4}$
}

\begin{abstract}
1. Residente, Programa de Residência Médica em Ortopedia e Traumatologia do Complexo Hospitalar Universitário Professor Edgard Santos, Universidade Federal da Bahia, Salvador, BA, Brasil. 2. Mestrando, Programa de Mestrado Profissional em Saúde Coletiva, Universidade Federal da Bahia, Salvador, BA, Brasil. 3. Preceptor, PRM em Ortopedia e Traumatologia do Complexo Hospitalar Universitário Professor Edgard Santos, Universidade Federal da Bahia, Salvador, BA, Brasil. 4. Professor Associado-Doutor, Chefe da Disciplina Cirurgia do Aparelho Locomotor, Departamento de Cirurgia Experimental e Especialidades Cirúrgicas, Faculdade de Medicina da Bahia, Universidade Federal da Bahia, Salvador, BA, Brasil
\end{abstract}

http://dx.doi.org/10.1590/1806-9282.66.12.1702

\section{SUMMARY}

OBJECTIVES: To describe the incidence by gender and region, lethality, and costs associated with the treatment of femoral fractures in the elderly ( $\geq 60$ years) hospitalized in the Unified Health System (SUS) of Brasil between 2008 and 2018.

METHODS: This is a cross-sectional, descriptive, retrospective study of hospitalizations of elderly people due to femoral fractures by analyzing secondary data obtained from the SUS Hospital Information System (SIH/SUS) between 2008 and 2018; for calculation of epidemiological coefficients, we used information from demographic censuses (2000 and 2010) of the Brazilian Geography and Statistics Institute (IBGE).

RESULTS: A total of 478,274 hospitalizations were recorded in the period; the incidence was 1.7 times higher in females (overall average of 274.91/100,000 for women and 161/100,000 for men). The Southeast region had the highest absolute number of hospitalizations and the South region presented the highest annual overall average incidence (224.02/100,000). The average annual cost for SUS for the treatment of femoral fractures in the elderly was $R \$ 99,718,574.30$.

CONCLUSIONS: In the evaluated period (2008-2018), femoral fractures in the elderly had a high incidence (478,274 hospitalizations; 224.02 cases/100,000 elderly), a predominance of females (1.7F/1.0M), a higher absolute number of hospitalizations in the Southeast region

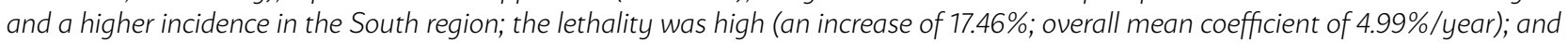
the costs for the SUS were huge (an increase of 126.24\%; average annual expenditure of $R \$ 99,718,574.30$ ).

KEYWORDS: Femoral fractures. Health services for the aged. Hospitalization. Health policy. Health systems agencies.

\section{INTRODUCTION}

Femoral fractures have a great social impact and financial burden on the health system. This impact is associated with extensive surgical procedures, long periods of hospitalization and patient recovery, and the potential for complications, sequels, and deaths inherent to this condition. 
The process of human aging is directly related to femoral fractures because the progressive physiological decrease of structural and functional reserves can create the conditions for a loss of bone continuity during moments of overload of the musculoskeletal system.

Femoral fractures in the elderly are associated with a greater length of hospitalization and rehabilitation and generate a high economic and social burden to their family members and the health system. In this age group, such fractures have a high incidence and are related to unfavorable outcomes, including the loss or decline of autonomy and quality of life: many of these patients do not resume their previous daily life activities (DLAs), suffer from psychological impact imposed by this condition, in addition to fearing new falls ${ }^{1.2}$. There are direct effects on the overall health of these individuals, particularly on account of immobilism, leading to increased rates of hospitalization and mortality ${ }^{2.3}$.

Studies highlight poor prognoses in elderly patients during the first postoperative year after the surgical treatment of fractures of the proximal segment of the femur ${ }^{2}$. Regarding hospital readmission, the study by Paula et al. ${ }^{2}$ showed a rate of $17.8 \%$ in the first year of follow-up postoperatively, especially secondary to surgical complications.

Campos et al. ${ }^{4}$ presented mortality rates at 3,6 , 9 , and 12 months of the postoperative follow-up of an elderly population who suffered a fracture of the proximal segment of the femur, identifying values of $21.2 \%, 25 \%, 28.8 \%$, and $34.6 \%$ for men and $7.8 \%, 13.5 \%$, $19.2 \%$, and $21.4 \%$ for women.

Given these findings, it appears that femoral fractures represent an actual public health problem, considering their significant negative impact in terms of overall incidence, lethality, and costs and their consequences for the public sector. In this sense, it is vital to identify the main epidemiological data related to this disease in the Brazilian population to support health policies and actions that can contribute to their prevention, the reduction of morbidity and lethality, and the reduction of costs by defining and standardizing guidelines to care for and follow-up on these patients, based on the best scientific evidence available.

The purpose of this study is to describe the incidence by gender and region, lethality, and costs associated with the treatment of femoral fractures in patients aged 60 years or older, hospitalized in the Single Health System (SUS) in Brasil between 2008 and 2018.

\section{METHODS}

A descriptive, retrospective, cross-sectional study was conducted on the hospitalizations of elderly patients with femoral fractures in the Single Health System (SUS) in Brasil between 2008 and 2018. We analyzed secondary data obtained from the Hospital Information System of SUS (SIH/SUS), of the Ministry of Health, and included cases of femoral fractures of the femur, based on the tenth revision of the International Classification of Diseases (ICD-10), in people aged 60 years or older.

The number of hospitalizations was evaluated in all regions of Brasil. The demographic data for calculation of epidemiological coefficients were obtained from the population censuses of 2000 and 2010, conducted by the Brazilian Institute of Geography and Statistics (IBGE). The data relating to the costs involved in elderly hospitalizations, i.e., the victims of femoral fractures, were obtained by tabulating the information available in the SIH/ SUS. Microsoft Excel ${ }^{\circledR}$ version 2010 spreadsheets were used to tabulate the data and make the statistical calculations.

No approval by the Human Research Ethics Committee was necessary because we used secondary information from a public domain database, per Resolution of the National Council of Health (CNS) No $466 / 2012$.

\section{RESULTS}

This study recorded 478,274 hospitalizations due to femoral fractures in people aged age 60 years or older in the SUS hospitals between January 2008 and December 2018, generating treatment costs that exceeded a billion reais (Table 1).

The overall incidence of femoral fractures in the Brazilian elderly had, in the analyzed period, an overall average of 224.02 cases per one 100,000 elderly individuals. The coefficient of lethality, i.e., hospitalized patients who progressed to death, showed an increase of $17.46 \%$, and the overall average of the coefficient, by $4.99 \%$ per year, while the costs increased $126.24 \%$ and had an average annual expenditure of $\mathrm{R} \$$ $99,718.574 .30$. The costs decreased only in the last year (Figure 1).

The incidence of femoral fractures by sex was 1.7 times higher in females when compared to males; in percentage values, there was a variation of $68.03 \%$ in 2008 and $68.22 \%$ in 2018 , with an overall average of 
274.91 per 100,000 for elderly women and 161 per 100,000 for elderly men.

The Southeast region had the greatest number of hospitalizations for all the years analyzed. However, the incidence of femoral fractures in the elderly in the South region, between 2008 and 2018, surpassed those in the Southeast region. From the year 2017, the Northeastern region had the lowest incidence of these fractures, but the figures were very close to those of the North region.

Regarding the lethality associated with hospitalizations due to femoral fractures, we observed a descending oscillation in the years 2009, 2013, and
2017 (Figure 2). On the other years, the coefficient of lethality remained on the rise, peaking in 2017.

\section{DISCUSSION}

In this study, we analyzed descriptively information relating to the distribution of hospitalizations of the elderly ( 60 years or older) due to femoral fractures in accredited hospitals of the public health system in Brasil, between January 2008 and December 2018, in addition to the coefficients of lethality and of the treatment costs relating to this disease. The results analyzed showed alarming numbers, considering the

FIGURE 2. OVERALL LETHALITY COEFFICIENT OF FEMORAL FRACTURES IN THE ELDERLY IN BRASIL, 2008 TO 2018. SOURCE: MINISTRY OF HEALTH- HOSPITAL INFORMATION SYSTEM OF SUS (SIH/SUS).

\begin{tabular}{l|l|l|l|l|l} 
Year & $\begin{array}{l}\text { Overall } \\
\text { elderly } \\
\text { population }\end{array}$ & $\begin{array}{l}\text { No. of } \\
\text { hospi- } \\
\text { taliza- } \\
\text { tions / } \\
\text { year }\end{array}$ & $\begin{array}{l}\text { No. of } \\
\text { deaths }\end{array}$ & $\begin{array}{l}\text { Mor- } \\
\text { tality }\end{array}$ & $\begin{array}{l}\text { Mort. } \\
\text { Specific } \\
\text { per } \\
100,000\end{array}$ \\
\hline 2008 & 14.536 .029 & 34.052 & 1.501 & 4,41 & 10,33 \\
\hline 2009 & 14.536 .029 & 35.847 & 1.711 & 4,77 & 11,77 \\
\hline 2010 & 20.590 .599 & 35.903 & 1.689 & 4,70 & 8,20 \\
\hline 2011 & 20.590 .599 & 38.297 & 1.837 & 4,80 & 8,92 \\
\hline 2012 & 20.590 .599 & 39.298 & 1.940 & 4,94 & 9,42 \\
\hline 2013 & 20.590 .599 & 41.839 & 2.118 & 5,06 & 10,29 \\
\hline 2014 & 20.590 .599 & 44.613 & 2.245 & 5,03 & 10,90 \\
\hline 2015 & 20.590 .599 & 46.974 & 2.415 & 5,14 & 11,73 \\
\hline 2016 & 20.590 .599 & 52.359 & 2.721 & 5,20 & 13,21 \\
\hline 2017 & 20.590 .599 & 55.654 & 2.943 & 5,29 & 14,29 \\
\hline 2018 & 20.590 .599 & 53.438 & 2.769 & 5,18 & 13,45 \\
\hline Total & - & 478.274 & 23.889 & 4,99 & - \\
\hline
\end{tabular}

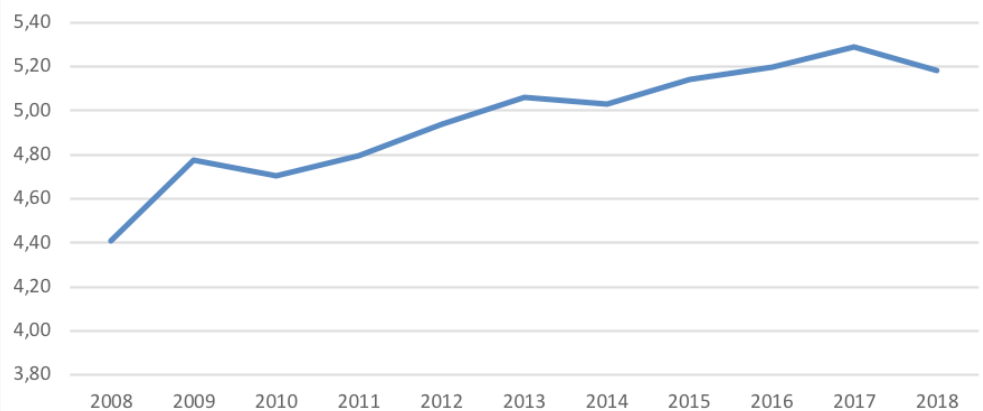

TABLE 1. HOSPITALIZATIONS DUE TO FEMORAL FRACTURES IN THE ELDERLY IN BRASIL, 2008 TO 2018.

\begin{tabular}{l|l|l|l|l|l|l}
$\begin{array}{l}\text { Year of } \\
\text { Treatment }\end{array}$ & $\begin{array}{l}\text { Hospitaliza- } \\
\text { tions }\end{array}$ & Deaths & Elderly Population & $\begin{array}{l}\text { Incidence per } \\
100,000\end{array}$ & Lethality & $\begin{array}{l}\text { Costs in Brazilian Reais/ } \\
\text { SUS (Public and Private) }\end{array}$ \\
\hline 2008 & 34,052 & 1,501 & $14,536,029$ & 234.26 & 4.41 & $61,244,495.61$ \\
\hline 2009 & 35,847 & 1,711 & $14,536,029$ & 246.61 & 4.77 & $68,731,712.18$ \\
\hline 2010 & 35,903 & 1,689 & $20,590,599$ & 174.37 & 4.70 & $73,622,107.30$ \\
\hline 2011 & 38,297 & 1,837 & $20,590,599$ & 185.99 & 4.80 & $79,272,817.63$ \\
\hline 2012 & 39,298 & 1,940 & $20,590,599$ & 190.85 & 4.94 & $83,720,115.34$ \\
\hline 2013 & 41,839 & 2,118 & $20,590,599$ & 203.19 & 5.06 & $98,328,317.70$ \\
\hline 2014 & 44,613 & 2,245 & $20,590,599$ & 216.67 & 5.03 & $108,382,558.85$ \\
\hline 2015 & 46,974 & 2,415 & $20,590,599$ & 228.13 & 5.14 & $114,525,068.42$ \\
\hline 2016 & 52,359 & 2,721 & $20,590,599$ & 254.29 & 5.20 & $130,097,650.56$ \\
\hline 2017 & 55,654 & 2,943 & $20,590,599$ & 270.29 & 5.29 & $140,416,282.49$ \\
\hline 2018 & 53,438 & 2,769 & $20,590,599$ & 259.53 & 5.18 & $138,563,191.21$ \\
\hline TOTAL & 478,274 & 23,889 & - & - & 4.99 & $1,096,904,317.29$ \\
\hline Average/year & 43,479 & 2,172 & $19,489,768$ & - & - & $99,718,574.30$ \\
\hline
\end{tabular}

Source: Ministry of Health - Hospital Information System of SUS (SIH/SUS). 
high rates of incidence and the important impact on the public budget.

Between 2008 and 2018, more than 470,000 hospitalizations were recorded due to femoral fractures in the elderly in the context of the SUS, with an average of approximately $43,479.45$ cases per year. These data are corroborated by the study by Soares et al. ${ }^{5}$, which found, from a five-year analysis considering the same profile of fractures and population, an expansion in the number of hospitalizations and an annual average of 32,600 cases.

Many of these elderly individuals have, in addition to a femoral fracture, multiple comorbidities, which further increase the risk for complications, hospital readmissions, and deaths ${ }^{2}$.

In addition to the high incidence and lethality observed, the total expenses with these fractures have exceeded 1 billion reais in the analyzed period, keeping the average annual costs with immediate and late treatments close to 99 million reais per year. The high costs imposed by this type of fracture were also was observed in other countries, such as Israel ${ }^{1}$, United States $^{5}$, Switzerland ${ }^{6}$ and Canada ${ }^{7}$; in the USA, the average cost of hospitalizations due to femoral fractures in 26,000 dollars ${ }^{5}$.

We found that most episodes of hospitalization due to femoral fractures in the elderly happened in females, with a percentage of $68.05 \%$ vs. $31.95 \%$ in males. These data are consistent with other studies carried out in Brasil and in other countries, which have shown a predominance of the incidence of this disease among the elderly ${ }^{5,7,8}$. Studies suggest that this happens because women begin the process of loss of bone mineral density before man $^{3,7,8}$.

A scientific bibliographic survey indicates that biological aging has structural and functional repercussions that accumulate progressively with the passing of the years, thus decreasing the motor capacity of the elderly ${ }^{9}$. Along with other comorbidities, this physiological decline means a greater chance of bone fragility and, consequently, fractures ${ }^{3,7,8}$.

As a result of the analysis of these data, it is clear that we are facing an important issue of public health, one that is complex and challenging due to five main factors: the high incidence of these fractures in recent years; the high cost of immediate and late treatments that burden the health budget; the psychological problems generated on patients due to the fear of new fractures, causing restrictions to DLAs ${ }^{3.10}$; the high lethality linked to this profile of patients and pathology; and finally, world aging is considered an irreversible process that must be dealt with in different ways in different countries but always with the intention of optimizing this process and reducing major diseases $\mathbf{~}^{\mathbf{7 , 8 1 0}}$.

The data in this research allude only to hospitalizations due to femoral fractures in the population aged 60 years or older who used public health services in Brasil. Thus, if we take into account that a large portion of the population also makes use of the private health system, surely it is possible to infer that the situation may be even worse.

A limitation of this study is the underreporting of events and possible coding errors regarding femoral fracture; the Hospital Information System (SIH) is considered a limited and flawed database, with imperfections regarding the overall reliability of its data. This is due to the absence of records regarding some services in partnership with the private system and complementary health system, managed by private health insurance companies and health cooperatives ${ }^{11}$.

It is clear that this is a disease with significant implications for the population in this age group, among them the decline in autonomy, functional capacity, and quality of life, constituting a complex public health problem.

Although the findings of this study are the results of a descriptive approach, they can be useful to better understand the occurrence of these fractures in the analyzed period and support the planning of public policies targeted at the elderly, thus aiming to inform and educate the population on the occurrence of these fractures, its complications, and health policies in favor of mechanisms to prevent new episodes, particularly in the more vulnerable age groups.

This way, we will be able to intervene effectively in factors that influence the events that lead to femoral fractures, thus reducing expenses and implementing better and lasting actions within the health and socioeconomic sphere.

\section{CONCLUSIONS}

In the assessed period (2008-2018), we identified that femoral fractures in the elderly in Brasil had a high incidence $(478,274$ hospitalizations, 224.02 cases/ 100,000 elderly), and females were more affected than males (1.7F/1.0M). The Southeast 
region had the highest absolute number of hospitalizations; however, it was surpassed in incidence by the South region.

There was a high lethality (an increase of $17.46 \%$, and an overall average of $4.99 \%$ per year for the coefficient).

There were substantial costs to the public health system (an increase of $126.24 \%$ and an average annual expenditure of $R \$ 99,718,574.30)$.

\section{Conflicts of interest}

The authors declare there are no conflicts of interest.

\section{Author's contributions}

Paula Antas Barbosa de Vasconcelos - Anderson de Jesus Rocha - concept and design, acquisition of data, or analysis and interpretation of data; drafting of the article or critical review of important intellectual content; Rodrigo Jorge de Souza da Fonseca - Thiago Rhangel Gomes Teixeira -concept and design, acquisition of data collection, or analysis, and interpretation; Enilton de Santana Ribeiro Mattos - (ICMJE) final approval of the version to be published; Alex Guedes - (ICMJE) final approval of the version to be published; accepted as responsible for all aspects of the work, ensuring that issues related to the accuracy or completeness of any part of the work are duly investigated and resolved.

\section{RESUMO}

OBJETIVOS: Descrever a incidência por gênero e região, a letalidade e os custos associados ao tratamento de fraturas do fêmur em idosos ( $\geq 60$ anos) internados no Sistema Único de Saúde (SUS) do Brasil entre 2008 e 2018.

MÉTODOS: Estudo transversal, descritivo e retrospectivo das internações de idosos por fraturas do fêmur mediante análise dos dados secundários obtidos do Sistema de Informações Hospitalares do SUS (SIH/SUS) entre 2008 e 2018; para cálculo dos coeficientes epidemiológicos, utilizamos informações dos censos demográficos (2000 e 2010) do Instituto Brasileiro de Geografia e Estatística (IBGE).

RESULTADOS: Foram registradas 478.274 mil internações no período. A incidência foi 1,7 vezes maior no gênero feminino (média geral de 274,91/100.000 para mulheres e 161/100.000 para homens). A região sudeste obteve maior número absoluto de internações e na região sul apresentou a maior incidência média geral anual (224,02/100.000). O custo médio anual do SUS para o tratamento das fraturas de fêmur em idosos foi de $R \$ 99.718 .574,30$.

CONCLUSÕES: No período avaliado (2008-2018), as fraturas do fêmur em idosos apresentaram alta incidência (478.274 mil internações; 224,02 casos/100.000 idosos), predomínio do gênero feminino (1,7F/1,0M), maior número absoluto de internações na região sudeste e maior incidência na região sul; a letalidade foi elevada (aumento de 17,46\%; média geral do coeficiente de 4,99\%/ano); e, os custos para o SUS foram vultuosos (aumento de 126,24\%, média anual de gastos de R\$99.718.574,30).

PALAVRAS-ChAVE: Fraturas do fêmur. Serviços de saúde para idosos. Hospitalização. Política de saúde. Órgãos dos sistemas de saúde.

\section{REFERENCES}

1. Barnea R, Weiss Y, Abadi-Korek I, Shemer J. The epidemiology and economic burden of hip fractures in Israel. Isr J Health Policy Res. 2018;7(1):38.

2. Paula FL, Cunha GM, Leite IC, Pinheiro RS, Valente JG. Readmissão e óbito de idosos com alta após internação por fratura proximal de fêmur, ocorrida nos hospitais do Sistema Único de Saúde entre os anos de 2008 e 2010, Rio de Janeiro. Rev Bras Epidemiol. 2015;18(2):439-53.

3. Neuburger J, Wakeman R. Is the incidence of hip fracture increasing among older men in England? J Epidemiol Community Health. 2016;70(10):1049-50.

4. Campos S, Alves SMF, Carvalho MS, Neves N, Trigo-Cabral A, Pina MF. Time to death in a prospective cohort of 252 patients treated for fracture of the proximal femur in a major hospital in Portugal. Cad Saúde Pública. 2015;31(7):1528-38.

5. Soares DS, Mello LM, Silva AS, Martinez EZ, Nunes AA. Fraturas de fêmur em idosos no Brasil: análise espaço-temporal de 2008 a 2012. Cad Saúde Pública. 2014;30(12):2669-78.

6. Mehra T, Moos RM, Seifert B, Bopp M, Senn O, Simmen HP, et al. Impact of structural and economic factors on hospitalization costs, in patient mortality, and treatment type of traumatic hip fractures in Switzerland. Arch Osteoporos. 2017;12(1):7

7. Soboley B, Guy P, Sheehan KJ, Kuramoto L, Bohm E, Beaupre L, et al; Canadian Collaborative Study on Hip Fractures. Time trends in hospital stay after hip fracture in Canada, 2004-2012: database study. Arch Osteoporos. 2016;11:13.

8. Soares DS, Mello LM, Silva AS, Nunes AA. Análise dos fatores associados a quedas com fratura de fêmur em idosos: um estudo caso-controle. Rev Bras Geriatr Gerontol. 2015;18(2):239-48.

9. Reis LA, Rocha TS, Duarte SFP. Quedas: risco e fatores associados em idosos institucionalizados. Rev Baiana Enferm. 2014;28(3):225-34.

10. Holloway KL, Sajjad MA, Mohebbi M, Kotowicz MA, Livingston PM, Khasraw $M$, et al. The epidemiology of hip fractures across western Victoria, Australia. Bone. 2018;108:1-9.

11. Souza MM, Souza EM, Nunes AA, Martinez EZ. Seasonal variation of femoral fractures in the state of São Paulo, Southeast Brasil. Rev Saude Publica. 2019;53:55. 